agriTECH, 40 (3) 2020, 232-241

\title{
Conduct and Performance of Catfish Marketing Channels in the Special Region of Yogyakarta, Indonesia
}

\author{
Teny Sylvia, Dyah Ismoyowati* \\ Department of Agro-Industrial Technology, Universitas Gadjah Mada, \\ Flora St. No. 1, Bulaksumur, Yogyakarta 55281, Indonesia \\ *Corresponding author: Dyah Ismoyowati, Email: dyah_ismoyowati@ugm.ac.id \\ Submission: March 4, 2019; Accepted: March 4, 2020
}

\begin{abstract}
Catfish is one of the leading fishery commodities in Indonesia. Its production is high in the Special Region of Yogyakarta, that is, $45.44 \%$ of the total aquaculture production and $35.58 \%$ of the total aquaculture production. This study aimed to determine the type of marketing channels, including the conduct and performance of catfish marketing, and the efficiency of catfish marketing in the Special Region of Yogyakarta. Samples were obtained through purposive and snowball sampling, and data were collected through in-depth interviews with 30 respondents and examined through descriptive analysis and an SCP approach focusing on conduct and performance analysis. Result showed that two marketing channels were available. The first type consisted of fish farmers, collectors, and retailers, and the second type included fish farmers and retailers. Market conduct analysis revealed that the determination of the catfish price was dominated by collectors, marketing costs varied among players, and the government did not intervene with its trade. Market performance analysis indicated that fish farmers received $71.98 \%$ of their share on marketing channel 1 and $80.49 \%$ on marketing channel 2 . The profit-to-cost ratios of collectors and retailers were 1.31 and 0.29 in marketing channel 1, respectively. In marketing channel 2, the profitto-cost ratio of retailers was 1.65 . Therefore, marketing channel 2 was more efficient than marketing channel 1 .
\end{abstract}

Keywords: Catfish; Conduct; Efficiency; Marketing Channel; Performance

\section{INTRODUCTION}

Indonesia is a maritime country rich in fish resources, including wild and aquaculture fisheries. According to the FAO's (2016) about aquaculture production figures and farmed fishery species, Indonesia ranks second in the category of the world's best fishery producers. This potential of Indonesian fishery can increase the economic growth if it is well managed. Juanti et al. (2014) indicated that fishery sectors have resources essential for the livelihood of the community and have the potential to become the main driver of the national economy.

In the Special Region of Yogyakarta, fisheries show potential for application in improving people's welfare if it is managed efficiently. Many people in Yogyakarta have their livelihoods in the fisheries. According to the Central Statistical Bureau, $81.05 \%$ of Yogyakarta people's livelihood is in agriculture, forestry, and fisheries (OCHA, 2014). The Central Statistical Bureau (2016) also stated that inland fisheries contribute $92 \%$ of total fishery production in Yogyakarta. Among the fishes, catfish is the most cultivated in Yogyakarta because it has a relatively high demand. Catfish contributes $45.44 \%$ of the total production and $35.58 \%$ of the total aquaculture production value in the Special Region of Yogyakarta (DKP, 2016).

The income of catfish farmers can be quite low, but no significant solution has been presented to deal with this problem. They only act as price takers because of their weak bargaining power in catfish marketing activities, thus severely affecting the income of catfish farmers. Fish marketing has several problems because fish is highly perishable, bulky, highly variable in size and weight among species, and costly in terms of storage and transportation; the quality and quantity of 
commodity are not guaranteed, and some fish kinds have low demand elasticity (inelastic) and widespread prices (Kumar et al., 2008). For instance, fresh fishes have a demand elasticity of -0.3 to -0.9 , which indicates that the demand is inelastic.

A negative mark in elasticity indicates that the fish price variable is inversely related to the demand for fish (Virgantari et al., 2011; Rizal et al., 2018). Upadhyay et al. (2016) demonstrated that the marketing of fishery commodities is crucial to achieve an efficient production system and customers' satisfaction. Moreover, fishery products are prone to loss. Post-harvest fish losses have seven types, namely, nutritional value loss, physical loss, quality loss, economic loss, market force loss, losses due to traditional processing, and distribution and storage loss (Jadhav \& Borgave, 2019).

Marketing efficiency is essential for fish farmers and other marketing actors to achieve maximum profits. In addition, one of the most important competitive advantages is being able to offer customers a product or service that has the same or better quality at a lower price than that provided by competitors. Reducing costs is complicated, so small profits can be important for businesses.

Price fluctuations and bargaining power of catfish farmers in markets are closely related to the conditions of a catfish market behavior in an area (Azhara, 2016). This market behavior affects market performance. Therefore, the conduct and performance of the catfish market should be examined to provide an overview of the efficiency of the catfish market in the Special Region of Yogyakarta.

Marketing efficiency indicators can be identified through a farmer's share, farmer's margin, and profitto-cost ratio ( $\mathrm{n} / \mathrm{c})$ of each marketing channel. However, fish farmers do not know how much their share is and how the marketing channel model reaches consumers, so the profits of fish farmers may still be improved. Therefore, this study was conducted to analyze the marketing of catfish in the Special Region of Yogyakarta by using the SCP approach and its marketing efficiency so that the most efficient marketing channel can be determined.

Previous studies explored the structure, conduct, and performance of fish marketing in Indonesia and other countries. Azhara (2016) focused on the SCP of milkfish marketing in West Java, which is a center of milkfish production in Indonesia. They found that six milkfish marketing channels exist in West Java. Their marketing actors include fish farmers, villages traders, wholesalers, retailers, and processors. If $\mathrm{CR}_{4}$ is close to 50 percent, the market structure at the wholesale level has a sufficiently high concentration. Therefore, the market structure is classified as a market with an imperfect competition, which can lead to inefficiencies in marketing practices. Besides, the highest marketing margin is found in marketing channel 2 (farmer-villages trader-wholesaler-retailer).

Apituley et al. (2018) investigated the SCP of flying fish marketing in Ambon City by analyzing the vertical market integration, price transmission elasticity, and price efficiency. They showed that the structure of the flying fish market leads to oligopoly. Besides, the marketing system in channel 3 is inefficient because of the large marketing margins and the small fishermen share because of the length of the channel.

Kumar et al. (2019) studied the SCP of the fish market in Khagaria District, India. They found three marketing channels, and marketing actors consist of producers, wholesalers, and retailers. Marketing channel 1 (produce-wholesaler-retailer-consumer) is the most common, and the highest producer share is found in the third channel (producer-consumer). The highest marketing efficiency, which is determined by economic efficient and technical efficiency, is also detected in the third channel. Thus far, studies on the marketing of catfish via the SCP approach have yet to be performed. Nevertheless, catfish has the highest production value in Yogyakarta and one of the leading commodities in aquaculture in Indonesia. Therefore, this research explored the marketing of catfish in the Special Region of Yogyakarta with the SCP approach.

\section{METHODS}

\section{Research Object}

Catfish marketing channels, including all the players, namely, fish farmers, collectors, and retailers, were used as the research object. This research was conducted in the Special Region of Yogyakarta through purposive sampling based on the area potential to improve the yield of catfish fisheries. This was brought about by the increasing demand for catfish because of the constantly increasing population and consumption per capita (Widodo et al., 2013). Moreover, the Special Region of Yogyakarta needs catfish supplies from other regions, such as Central Java and East Java, showing that the Special Region of Yogyakarta has a market opportunity in catfish. The research locations included the subdistricts of Moyudan, Ngaglik, Ngemplak, and Sayegan in Sleman Regency; the subdistricts of Pengasih, Wates, and Temon in Kulon Progo Regency; and the subdistricts of Jetis, Piyungan, and Sanden in Bantul Regency. These subdistricts were chosen because they had high catfish production rates, and catfish farmers 
had continuous catfish farming activities. This research was conducted from January 2018 to March 2018.

\section{Data Collection}

Data were collected through observation and indepth interviews with 30 respondents determined via purposive sampling and snowball sampling. Furthermore, 12 respondents were from Sleman, 9 respondents were from Kulon Progo, and 9 were respondents from Bantul. Catfish farmers who served as the starting point of the marketing channel were selected through purposive sampling. The consideration was that farmers have a catfish cultivation business as their livelihood and have been in this business for at least 2 years. Then, snowball sampling was conducted by following the flow of the supply chain up to consumers who were the destination point to obtain information about actors and activities that occurred along the supply chain of catfish in Yogyakarta.

Primary data, including production quantity, sales quantity, purchasing price, selling price, and marketing costs in all tiers, namely, fish farmers, collectors, and retailers, were used. Furthermore, secondary data consisting of catfish production and aquaculture production value in the Special Region of Yogyakarta were considered.

\section{Methods of Analysis}

Data were analyzed using the SCP approach that involved qualitative and quantitative analysis. Qualitative analysis was conducted to determine the market conduct (how to buy, sell, and pay) and the market performance in the form of marketing channels, prices, costs, and sales volume. Quantitative analysis was carried out to identify the marketing efficiency by calculating marketing margins, farmer's share, and profit-to-cost ratio.

The components, namely, the conduct and performance of market, were explained in detail by using the SCP approach (Pradika et al., 2013):
a. Market conduct
1. Transaction practices
2. Price determination

b. Market performance

1. Marketing channel

2. Price, cost, and sales volume

3. Farmer's share

Farmer's share is a comparison of prices at the producer level with prices at the consumer level. Farmer's share analysis aims to determine the price part received by catfish farmers. If the farmer's share is high, then market performance is better from the perspective of a fish farmer (producer). Farmer's share is calculated as follows (Equation 1).

$F_{s}=\left(P_{f} P_{r}\right) \times 100 \%$,

where $F_{s}$ is the share of catfish price received by fish farmers, $P_{f}$ is the catfish price in the tier of fish farmers, and $P_{r}$ is the catfish price in the tier of consumers.

4. Marketing margin

Marketing margin is used to estimate marketing performance. This parameter indicates the relative cost of marketing at a particular time and can be used to determine business profitability (Akinyemi et al., 2017). Marketing margin analysis is performed to determine the price difference between the tier of fish farmers $\left(P_{f}\right)$ and the tier of consumers $\left(P_{r}\right)$. Marketing margin is calculated with Equation 2 , and the total marketing margin is expressed in Equation 3.

$$
\begin{aligned}
& M j_{i}=P s_{i}-P b_{i} \\
& \sum M_{i}=P_{r}-P_{f \prime}
\end{aligned}
$$

where $\mathrm{Mj}_{\mathrm{i}}$ is the margin at the level of marketing actor-i, $\Sigma \mathrm{Mj}_{\mathrm{i}}$ is the total of marketing margin, $\mathrm{Ps}_{\mathrm{i}}$ is the selling price at the level of marketing actor-i, $\mathrm{Pb}_{\mathrm{i}}$ is the purchasing price at an i-level marketing institution, $P_{r}$ is the price at the consumer level, and $\mathrm{P}_{\mathrm{f}}$ is the price at the producer level $\mathrm{i}=1,2,3, \ldots, \mathrm{n}$.

Walter and Etany (2018) indicated that marketing margin is the difference between selling and buying prices. The fluctuation of marketing margin depends on the perishability of a product and the number of actors in marketing channels. The marketing services provided and the risk and uncertainty of each of the market actors. The obtained marketing margin indicates the percentage share received by producers from consumers (Tijani et al., 2014).

A marketing system is expected to be efficient because it can affect the income and satisfaction of marketing players. Fish farmers need several marketing actors to distribute their products quickly and precisely so that they can reach a wider market. The fluctuating price level creates a fluctuating marketing margin. The distribution of marketing margins can be observed on the basis of the percentage of profit-to-cost ratio in each marketing player (Equation 4).

$$
\Pi / \mathrm{c}=\Pi_{\mathrm{i}} / \mathrm{bt} \mathrm{i}_{\mathrm{i}}
$$

where $n / c$ is the profit-to-cost ratio, $\Pi_{i}$ is the profit at the level of marketing actor-i, and $b t_{i}$ is the marketing cost at the level of marketing actor-i. 
A profit-to-cost ratio that is evenly distributed at various marketing levels is a reflection of an efficient marketing system. In particular, the marketing system is efficient if the profit-to-cost ratio of marketing actors is equal to zero; otherwise, the marketing system is inefficient. Situmorang et al. (2015) also indicated that if the profit-to-cost ratio $(n / c)$ is more than one $(n / c>1)$, then a marketing activity is profitable. Otherwise, this activity is not profitable.

Asmarantaka (2014) and Erzal et al. (2015) showed that marketing is operationally efficient if the ratio of the output value is proportional to the input value of marketing carried out by the actors. Quantitatively, marketing efficiency can be determined with three indicators, namely, low marketing margin, high farmer share $(>50 \%)$, and relatively similar profit-to-cost ratios among marketing actors.

\section{RESULTS AND DISCUSSION}

\section{Catfish Marketing Channels}

The following marketing conditions of catfish were analyzed: marketing actors, marketing activities, and marketing channel patterns in Sleman, Kulon Progo, and Bantul Regencies.

\section{Marketing Players}

Catfish marketing players include catfish farmers, collectors, and retailers. As producers, some fish farmers join a group, while others are individual fish farmers. Collectors are the ones who become brokers that further sell catfish to other traders. In general, collectors buy in bulk, which consists of 7-12 tails/kg, from fish farmers and then sell it to other traders or retailers. Others may buy per pool, that is, they buy all the fish harvested in a pool. They also sell catfish to retailers in traditional markets, fishing pool owners, and restaurant owners, such as Padang restaurants and tent stalls.

Retailers are the last player of catfish marketing channels. They may buy catfish from collectors or directly from catfish farmers. Retailers who sell in traditional markets are the most common players that have the highest quantity of purchase among other types of retailers, such as peddlers or individuals who sell in stores in their homes. Retailers in this traditional market may offer catfish to industrial and household consumers, street vendors, or vegetable stall owners at home.

\section{Marketing Activities}

Marketing has three main functions: (i) exchange (selling and purchasing), (ii) physical (storage, sortation, and transportation), and (iii) facility provider (cost, risk, and marketing information; Kiuk et al., 2018). The marketing activities carried out by catfish farmers, collectors, and retailers are shown in Table 1.

Our observations show that catfish marketing actors have three marketing functions, namely, exchange, physical, and facility provider functions. Although each marketing person plays the same marketing function, the activities of individuals slightly differ. For example, sorting activities vary at the level of fish farmers, collectors, and retailers. Fish farmers sort catfish in sizes of $5-12 \mathrm{fish} / \mathrm{kg}$ to meet the needs of customers as collectors. Then, collectors sort catfish, but they do it in detail. They are accustomed to doing this before delivery because each customer needs a different size of catfish; for instance, industrial customers require

Table 1. Functions of catfish marketing actors in the Special Region of Yogyakarta

\begin{tabular}{|c|c|c|}
\hline $\begin{array}{l}\text { Marketing } \\
\text { Actor }\end{array}$ & $\begin{array}{l}\text { Marketing } \\
\text { Function }\end{array}$ & Activity \\
\hline \multirow[t]{3}{*}{ Fish farmer } & Exchange & Sales (catfish consumption size $5-12$ tails $/ \mathrm{kg}$ ) \\
\hline & Physical & Sorting, packaging, transportation \\
\hline & Facility provider & $\begin{array}{l}\text { Financing (business capital/capital loans), collection, risk coverage (price } \\
\text { fluctuations, production risk, and loss), market information } \\
\text { Purchase and sale (catfish consumption) }\end{array}$ \\
\hline \multirow[t]{3}{*}{ Collector } & Exchange & Storage, sorting, cleaning, packaging, transportation \\
\hline & $\begin{array}{l}\text { Physical } \\
\text { Facility provider }\end{array}$ & $\begin{array}{l}\text { Collection, financing (business capital loans), risk coverage (price and loss } \\
\text { fluctuations), market information }\end{array}$ \\
\hline & & Purchase and sale \\
\hline \multirow[t]{3}{*}{ Retailer } & Exchange & Storage and transport, packaging, cleaning, sorting \\
\hline & Physical & Market information, risk coverage (price and loss fluctuations) \\
\hline & Facility provider & \\
\hline
\end{tabular}




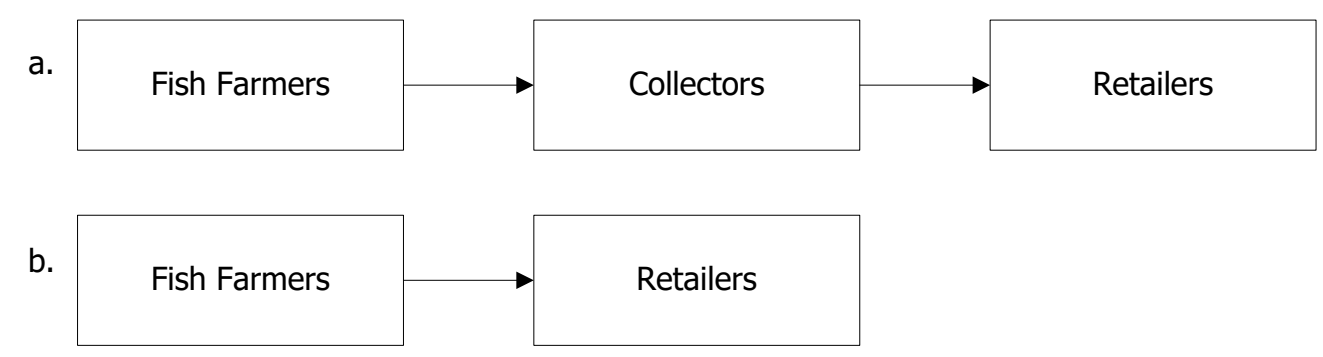

Figure 1. Catfish marketing channel in the Special Region of Yogyakarta

a. First type of marketing channels and b. second type of marketing channels

5-6 fish $/ \mathrm{kg}$, while retailers need $7-12 \mathrm{fish} / \mathrm{kg}$. At the next level, retailers sort catfish according to customers' requests, but they do so in a place where customers come to buy it.

\section{Marketing Channel}

In the catfish fishery system in the Special Region of Yogyakarta, marketing actors generally have two types: the first one includes fish farmers, collectors, and retailers, whereas the second one consists of fish farmers and retailers. Here, 30 respondents were interviewed: 11 fish farmers, 1 fish farmer and collector, 8 collectors, 1 collector and retailer, and 9 retailers in traditional markets.

\section{Conduct and Performance}

\section{Marketing Conduct}

In general, transaction practices involve the selling of catfish by fish farmers to collectors. When selling catfish, fish farmers directly participate in harvesting catfish, and some fish farmers harvest catfish by themselves. Otherwise, collectors are the ones engaged in harvesting activities. Collectors sell catfish by delivering it directly to their customers, namely, retailers in traditional markets. Furthermore, some retailers buy and take catfish directly to collectors' location.

The price determination system of catfish in the tier of fish farmers, collectors, and retailers refers to prices prevailing in the market. The pricing of catfish in the tier of fish farmers is carried out by collectors. Collectors buy large amounts of catfish so that they have a higher bargaining power in the pricing system. In determining catfish price, collectors consider the market price, which is based on the number of catfish supply and the number of consumers' requests. Collectors obtain information about the demand and selling price of catfish from retailers in markets. If the fish supply is abundant, then its price decreases. Furthermore, the catfish price in the Special Region of Yogyakarta is influenced by the catfish supply from areas outside Yogyakarta, such as Boyolali, Central Java, and Tulung Agung, East Java to the market.

Two payment systems, namely, cash and deferred payment, are applied. The deferred payment system is used in the tier of retailers to collectors. However, collectors indicate that this system is allowed for retailers based on good relationships and reputation developed over time because of the high frequency of purchasing by retailers. The cooperative relationship that exists between fish farmers, collectors, and retailers is based on mutual trust and good relations. These actors have no formal written cooperation system or contract.

\section{Market Performance}

Widyaningtyas et al. (2014) indicated that market performance can be used to determine the degree of the influence of market behavior in catfish marketing. Market performance can be measured by analyzing marketing margins and farmer's share. Marketing margin analysis is a quantitative measurement tool used to assess marketing efficiency, which is defined as the difference in price received by fish farmers and the price paid by the end consumer. This difference is attributed to marketing costs incurred by each actor involved to increase the added value of products. Furthermore, the price difference is caused by the addition of markups or profits of sellers. Rahman et al. (2017) showed that the price of fish may be affected by many factors, such as species, size, consumers' demand, distance, quantity, and quality.

The marketing margin consists of two components, namely, profit and marketing costs. The marketing cost of catfish covers the costs of harvesting, transportation, packaging, depreciation, storage, and shipping. The calculation results of the marketing margin of catfish in each marketing channel are presented in Tables 2, 3, 4, and 5 . Marketing margin can be obtained by calculating the difference between the buying price (price at the customer level) and the selling price (price at the 
Table 2. Analysis of the marketing margin of catfish in the Sleman District in January-March 2018

\begin{tabular}{|c|c|c|c|c|c|}
\hline No & Marketing players & Channel 1 (IDR/kg) & Share (\%) & Channel 2 (IDR/kg) & Share (\%) \\
\hline \multirow[t]{2}{*}{1} & Fish farmer & & & & \\
\hline & Selling price & $15,578.00$ & 73.60 & $17,500.00$ & 79.55 \\
\hline \multirow[t]{6}{*}{2} & Collector & & & & \\
\hline & Buying price & $15,578.00$ & 73.60 & & \\
\hline & Marketing cost & 960.62 & 4.54 & & \\
\hline & Profit & $2,036.38$ & 9.62 & & \\
\hline & Selling price & $18,575.00$ & 87.76 & & \\
\hline & Margin & $2,997.00$ & & & \\
\hline \multirow[t]{7}{*}{3} & Retailer & & & & \\
\hline & Buying price & $18,575.00$ & 87.76 & $17,500.00$ & 79.55 \\
\hline & Marketing cost & $2,556.99$ & 12.08 & $1,306.42$ & 5.94 \\
\hline & Profit & 34.68 & 0.16 & $3,193.58$ & 14.52 \\
\hline & Selling price & $21,166.67$ & 100.00 & $22,000.00$ & 100.00 \\
\hline & Margin & $2,591.67$ & & $4,500.00$ & \\
\hline & Total margin & $5,588.67$ & 26.40 & $4,500.00$ & 20.45 \\
\hline
\end{tabular}

Source: Processed primary data (2018)

marketing agent level). Furthermore, the total margin is determined by adding all the margins at each marketing level in the same channel.

In Table 2, the total margin in marketing channel 1 is the highest, that is, IDR of $5,588.67 / \mathrm{kg}$. However, the marketing margin at the retail level is the highest in marketing channel 2, that is, IDR of $4,500 / \mathrm{kg}$. By contrast, in marketing channel 1 , the IDR is $2,591.67 /$ $\mathrm{kg}$. Marketing margin can be influenced by many factors, such as sales volume and distance of marketing locations, number of players involved in the marketing chain, the functions of marketing carried out by marketing players, and market type.

Table 2 also shows that marketing channel 2 gives a higher farmer's share, which is an average of $79.55 \%$. The high proportion of the price received by farmers is influenced by the high selling price of catfish farmers to the price of retailers as the final catfish marketing actor in the Special Region of Yogyakarta. Furthermore, the number of marketing actors involved is less than that in marketing channel 1 , and marketing functions are carried out by each marketing actor. However, from the consumers' perspective, marketing channel 2 provides a higher price than marketing channel 1 , which has a longer supply chain. This phenomenon shows that a shorter supply chain of marketing channels does not always provide cheaper prices to consumers. In the case of farmers in Sleman (channel 2), specifications are set for certain catfish being sold. Farmers sell catfish with a size of $5-7$ tails $/ \mathrm{kg}$, while other farmers sell catfish with a size of $6-12$ tails $/ \mathrm{kg}$. Therefore, consumers want to pay more because the quality of catfish sold by farmers in marketing channel 2 is better than that in marketing channel 1 , but the size of catfish is the same as customers' desired. Although the quantity of fish sold per day is fluctuating between 140 and 150 $\mathrm{kg} / \mathrm{day}$, this quantity of sales is quite larger than that of other retailers. This result indicates that the demand for catfish in this market is high enough so that it can influence the determination of catfish price.

Table 2 shows the profit-to-cost ratio of each marketing channel. In marketing channel 1 , the profitto-cost ratio of collectors is 2.11 , while the profit-tocost ratio of retailers is 0.013 . In marketing channel 2 , the profit-to-cost ratio on retailers is 2.44 . According to Situmorang et al. (2015), the profit-to-cost ratio is used to determine the distribution of profits and incurred expenses by marketing players. Therefore, marketing efforts carried out by all marketing actors except retailers on marketing channel 1 provide profits. Retailers in marketing channel 1 have a profit-to-cost ratio of less than $1(n / c<1)$, which suggests that the actor's marketing efforts are not profitable. Although the catfish business does not provide profit, retailers still gain income, so they have created jobs for themselves.

In Table 3, the marketing margin in marketing channel 1 is much higher than that in marketing channel 2 , i.e., IDR of $6,795 / \mathrm{kg}$, and it is the highest margin in the Special Region of Yogyakarta. Having the difference with the analysis of marketing margins in Sleman Regency as it is shown in Table 5, in the analysis of marketing margins in Kulon Progo Regency, the margin of each marketing actor in marketing channel 1 is greater than that in marketing channel 2. The farmer's share in marketing channel 2 is larger (81.58\%) than marketing channel 1 in the Special Region of Yogyakarta. 
Table 3. Analysis of the marketing margin of catfish in Kulon Progo District in January-March 2018

\begin{tabular}{|c|c|c|c|c|c|}
\hline No & Marketing player & Channel 1(IDR/kg) & Share (\%) & Channel 2 (IDR/kg) & Share (\%) \\
\hline \multirow[t]{2}{*}{1} & Fish farmer & & & & \\
\hline & Selling price & $15,130.00$ & 69.01 & $15,500.00$ & 81.58 \\
\hline \multirow[t]{6}{*}{2} & Collector & & & & \\
\hline & Buying price & $15,130.00$ & 69.01 & & \\
\hline & Marketing cost & $1,344.84$ & 6.13 & & \\
\hline & Profit & $1,275.16$ & 5.82 & & \\
\hline & Selling price & $17,750.00$ & 80.96 & & \\
\hline & Margin & $2,620.00$ & & & \\
\hline \multirow[t]{7}{*}{3} & Retailer & & & & \\
\hline & Buying price & $17,750.00$ & 80.96 & $15,500.00$ & 81.58 \\
\hline & Marketing cost & $2,306.04$ & 10.52 & $1,713.40$ & 9.02 \\
\hline & Profit & $1,868.96$ & 5.07 & $1,786.60$ & 9.40 \\
\hline & Selling price & $21,925.00$ & 100 & $19,000.00$ & 100.00 \\
\hline & Margin & $4,175.00$ & & $3,500.00$ & \\
\hline & Total margin & $6,795.00$ & 19.04 & $3,500.00$ & 18.42 \\
\hline
\end{tabular}

Source: Processed primary data (2018)

In Table 3, the profit-to-cost ratios of collectors and retailers in marketing channel 1 are 0.95 and 0.81 , respectively. In marketing channel 2 , the profit-to-cost ratio is 1.04 . This value indicates that collectors and retailers in marketing channel 1 do not earn profits because the profit-to-cost ratio $(\Pi / \mathrm{c})$ is less than 1 . In marketing channel 2 , the marketing efforts of retailers provide profits.

In Table 4, only marketing channel 1 is found by the researchers. It is the channel mostly detected in

Table 4. Analysis of the marketing margin of catfish in Bantul District in January-March 2018

\begin{tabular}{llcc}
\hline No & Marketing player & $\begin{array}{c}\text { Channel } 1 \\
(\text { IDR/kg) }\end{array}$ & Share (\%) \\
\hline 1 & Fish farmer & & \\
& Selling price & $15,666.67$ & 73.44 \\
2 & Collector & & \\
& Buying price & $15,666.67$ & 73.44 \\
& Marketing cost & 955.49 & 4.48 \\
& Profit & 977.84 & 4.58 \\
& Selling price & $17,600.00$ & 82.50 \\
& Margin & $1,933.33$ & \\
Retailer & & \\
Buying price & $17,600.00$ & 82.50 \\
& Marketing cost & $3,249.38$ & 15.23 \\
& Profit & 483.95 & 2.27 \\
& Selling price & $21,333.33$ & 100.00 \\
Margin & $3,733.33$ & \\
Total Margin & $5,666.66$ & 26.56 \\
\hline
\end{tabular}

Source: Processed Primary Data (2018) the Special Region of Yogyakarta. The marketing margin of catfish in the Bantul Regency is IDR of 5,666.66/kg, and the highest margin is provided by retailers, that is, IDR of $3,733.33 / \mathrm{kg}$. The farmer's share of the catfish marketing system in Bantul Regency is $73.44 \%$. The profit-to-cost ratios $(n / \mathrm{c})$ of collectors and retailers in marketing channel 1 in Bantul Regency are 1.023 and 0.15 , respectively. These results indicate that the business of marketing collectors provides profit, whereas retailers do not provide profit.

Table 5 shows the recapitulation results of the average marketing margin in Sleman, Kulon Progo, and Bantul Regencies. Marketing channel 1 shows the highest margin of IDR of $6,016.78 / \mathrm{kg}$, whereas the farmer's share is $71.98 \%$. In marketing channel 2 , the margin is IDR of $4,000 / \mathrm{kg}$, and its share is $80.49 \%$. This result suggests that the higher the number of marketing players involved, the lower the part of the price that farmers receive from those paid by consumers (farmer's share).

From all marketing channels in each district, marketing channel 2 in Kulon Progo Regency is the most efficient because it has the smallest margin (IDR of $3,500 / \mathrm{kg}$ ) and the highest farmer's share (81.58\%). From the consumer's perspective, marketing channel 2 in Kulon Progo is the best because it provides the lowest prices for consumers and benefits to its marketing actor (retailers).

Based on the average profit-to-cost ratio of marketing actors in the Special Region of Yogyakarta, the profit-to-cost ratios $(\mathrm{n} / \mathrm{c})$ of collectors and retailers in marketing channel 1 are 1.31 and 0.29 , respectively. 
Table 5. Analysis of the marketing margin of catfish in the Special Region of Yogyakarta in January-March 2018

\begin{tabular}{|c|c|c|c|c|c|}
\hline No & Marketing player & Channel 1 (IDR/kg) & Share $(\%)$ & Channel 2 (IDR/kg) & Share $(\%)$ \\
\hline \multirow[t]{2}{*}{1} & Fish farmer & & & & \\
\hline & Selling price & $15,458.22$ & 71.98 & $16,500.00$ & 80.49 \\
\hline \multirow[t]{6}{*}{2} & Collector & & & & \\
\hline & Buying price & $15,458.22$ & 71.98 & & \\
\hline & Marketing cost & $1,086.98$ & 5.06 & & \\
\hline & Profit & $1,429.79$ & 6.66 & & \\
\hline & Selling price & $17,975.00$ & 83.70 & & \\
\hline & Margin & $2,516.78$ & & & \\
\hline \multirow[t]{7}{*}{3} & Retailer & & & & \\
\hline & Buying price & $17,975.00$ & 83.70 & $16,500.00$ & 80.49 \\
\hline & Marketing cost & $2,704.14$ & 12.59 & $1,509.91$ & 7.37 \\
\hline & Profit & 795.86 & 3.71 & $2,490.09$ & 12.15 \\
\hline & Selling price & $21,475.00$ & 100.00 & $20,500.00$ & 100.00 \\
\hline & Margin & $3,500.00$ & & $4,000.00$ & \\
\hline & Total margin & $6,016.78$ & 28.02 & $4,000.00$ & 19.51 \\
\hline
\end{tabular}

Source: Processed primary data (2018)

In marketing channel 2 , the profit-to-cost ratio $(n / c)$ is 1.65. This finding shows that marketing efforts carried out by collectors in marketing channel 1 and retailers in marketing channel 2 gain profits, whereas marketing efforts by retailers in marketing channel 1 do not provide profits.

Ohen (2017) indicated that the efficiency of the marketing system of catfish can be maintained by improving the transportation system, including the development of a better fish carriage system to reduce fish stress and marketing losses. Marketing loss is one of the post-harvest fish lose. Moreover, players, especially fish farmers, should be linked to new market opportunities outside the present market. Furthermore, the government and other related stakeholders should create a supporting environment to help marketing players, especially fish farmers, access a loan. Some fish farmers borrow capital from collectors to meet the cost of producing catfish. Loans can be used as a capital to run a business, such as buying feed, because the demand for feed is quite high, and its price is quite expensive.

\section{CONCLUSIONS}

The catfish marketing channel patterns in the Special Region of Yogyakarta have two types. Marketing channel 1 consists of three marketing players consisting of fish farmers, collectors, and retailers. Marketing channel 2 includes two marketing actors, namely, farmers and retailers. Each marketing actor helps others in carrying out marketing functions. The market conduct in catfish marketing shows that the pricing determination of catfish is dominated by collectors, marketing costs vary among players, and the government does not intervene with trade policy. The catfish market performance in the Special Region of Yogyakarta indicates that fish farmers receive $71.98 \%$ share in marketing channel 1 and $80.49 \%$ share in marketing channel 2 . The collectors' and retailers' profit-to-cost ratios are 1.31 and 0.29 in marketing channel 1 , respectively. In marketing channel 2 , the retailers' profit-to-cost ratio is 1.65 . These results indicate that marketing channel 2 is more efficient than marketing channel 1. In Kulon Progo Regency, marketing channel 2 is also more efficient in the Special Region of Yogyakarta because it has the highest farmers' share, provides benefits to other marketing actors (retailers), and offers the lowest prices to consumers. Fish farmers' access to formal financial institutions, such as banks and nonbanks, should be improved. Besides useful to improve fish farmer productivity, it can also reduce fish farmers' dependence on collectors. With the reduced fish farmers' dependence on collectors as capital providers, fish farmers have various choices of marketing channels to improve their bargaining power. Furthermore, improving the access of fish farmers to market information can increase their bargaining power in determining the price of catfish.

\section{CONFLICT OF INTEREST}

The authors declare no conflict of interest in this research. 


\section{REFERENCES}

Akinyemi, S. O. S., Adejoro, M. A., Layade, A. A., \& Adegbite, O. O. (2017). Market Structure and Performance for Plantain and Banana. International Journal of Fruit Science, 17(4), 440-450. https://doi.org/10.1080/1553 8362.2017.1360231

Apituley, Y. M., Lopulalan, Y., Salakory, R. A., \& Bawole, D. (2018). Market Structure, Conduct and Performance of Scad (Decapterus russeli) in Kota Ambon. Jurnal Manajemen dan Agribisnis, 15(3), 221-229. https://doi. org/10.17358/jma.15.3.221

Asmarantaka, R. (2014). Pemasaran Agribisnis (Agrimarketing). Bogor: PT Penerbit IPB Press

Azhara, D. (2016). Struktur, Perilaku dan Kinerja Pemasaran Ikan Bandeng Di Jawa Barat. Retrieved from https:// repository.ipb.ac.id/handle/123456789/82692

Central Statistical Bureau. (2016). Provinsi Daerah Istimewa Yogyakarta Dalam Angka 2016. Retrieved from https://jogjakota.bps.go.id/publication/2016/07/15/ a81ad53935e65a5e7c55e0f8/kota-yogyakarta-dalamangka-2016.html

DKP. (2016). Buku Monografi Dinas Kelautan dan Perikanan Daerah Istimewa Yogyakarta Tahun 2015. Yogyakarta: Dinas Kelautan dan Perikanan DIY

Erzal, M., Taslim, \& Masdar, A. (2015). Marketing Channel, Margin, and Efficiency Analysis of Local Broiler Duck. Jurnal Fakultas Peternakan Universitas Padjadjaran, $5(1), 1-12$

FAO. (2016). The State of World Fisheries and Aquaculture Contributing to Food Security and Nutrition for All. Retrieved from http://www.fao.org/3/a-i5555e.pdf

Jadhav, G., \& Borgave, S. (2019). Marine Fish Marketing System and Distribution Channels in India: A Literature Review. International Journal of Research and Analytical Reviews, 6(2), 998-1003. https://doi.org/10.13140/ RG.2.2.20261.45286

Juanti, F., Jumiati, A., \& Santoso, E. (2014). Economic Landscape Sub Sektor Perikanan Pada Perekonomian Kabupaten Sidoarjo: Model Input Output dan Analytical Hierarchy Process. E-Journal Ekonomi Bisnis Dan Akuntansi, 1 (1). Retrieved from https://doi.org/https, 42-52. https://doi.org/10.19184/ejeba.v1i1.569

Kiuk, J. W., Rehatta, B. M., \& Ninef, J. S. R. (2018). Fresh Fish Marketing Analysis of Small-Scale Fisheries in Belu, East Nusa Tenggara of Indonesia. Russian Journal of Agricultural and Socio-Economic Sciences, 83(11), 369374. https://doi.org/10.18551/rjoas.2018-11.44

Kumar, G. B., Datta, K. K., Joshi, P. K., Katiha, P. K., Suresh, R., Ravisankar, T., \& Menon, M. (2008). Domestic Fish Marketing in India-Changing Structure, Conduct, Performance and Policies. Agricultural Economics Research Review, 21(January), 345-354. https://doi. org/10.22004/ag.econ.47884
Kumar, R. S., Kumar, D. K., \& Prakash, S. (2019). Structure, Conduct and Performance of Fish Markets of Khagaria District. International Journal of Research in Business. Economics and Management, 3(4), 1-13. Retrieved from http://www.ijrbem.com/doc/142.pdf

OCHA. (2014). Province Infographic-DI Yogyakarta. OCHA

Ohen, S. (2017). Structure, Conduct and Performance of Fresh Farmed Catfish Marketing System in Delta State, Nigeria. IOSR Journal of Business and Management (IOSR-JBM), 19(9), 53-60. https://doi. org/10.9790/487X-1909035360

Pradika, A., Hasyim, A., \& Soelaiman, A. (2013). Analysis of the Marketing Efficiency of Sweet Potato in Central Lampung Regency. Jurnal Ilmu-IImu Agribisnis, 1(1), 27-35. https://doi.org/10.23960/jiia.v1i1

Rahman, M. A., Akter, S., Bhowmik, S., Pramanik, M. M. H., \& Alam, A. N. (2017). Fish in Super-Shops: A New Dimension of Fish Marketing System in Dhaka (Bangladesh). Journal of Fisheriessciences.com, 11(1), 37-42. https://doi.org/10.21767/1307-234x.1000105

Rizal, A., Aprilia, L., Nurruhwati, I., \& Nurhayati, A. (2018). The Elasticity of Demand for Catfish Products (Clarias sp.) in Bandung City of Indonesia. World Scientific News, 102, 76-89. Retrieved from https://www.researchgate.net/ publication/325811982_The_Elasticity_of_Demand_ For_Catfish_Products_Clarias_sp_In_Bandung_City_of_ Indonesia

Situmorang, T. S., Alamsyah, Z., \& Naenggolan, S. (2015). Analisis Efisiensi Pemasaran Sawi Manis Dengan Pendekatan Structure, Conduct, and Performance (SCP) Di Kecamatan Jambi Selatan Kota Jambi. Jurnal Ilmiah Sosio-Ekonomika Bisnis, 18(2), 79-89. https://doi. org/10.22437/jiseb.v18i2.2830

Tijani, B., Abdlatif, I., Goni, M., \& Fannami, A. (2014). Analysis of Conduct and Performance of Dried Fish Market in Maiduguri Metropolis of Borno State, Nigeria. Journal of Economics and Sustainable Development, 5(5), 38-46

Upadhyay, A. D., Jagpal, \& Roy, P. D. (2016). Structural Performance of Fish Market and Socio-Economic Status of Market Functionaries of Naveen Machhali Mandi Mahanva of Gorakhpur, Uttar Pradesh. Economic Affairs, 61(3), 511-518. https://doi.org/10.5958/09764666.2016.00064.4

Virgantari, F., Daryanto, A., Harianto, H., \& Kuntjoro, S. U. (2011). Analisis Permintaan Ikan Di Indonesia: Pendekatan Model Quadratic Almost Ideal Demand System (Quaids). Jurnal Sosial Ekonomi Kelautan dan Perikanan, 6(2), 191-203. https://doi.org/10.15578/ jsekp.v6i2.5772

Odongo, W., \& Etany, S. (2018). Value Chain and Marketing Margins of Cassava: An Assessment of Cassava Marketing in Northern Uganda. African Journal of Food, Agriculture, Nutrition and Development, 18(1), 1322613238. https://doi.org/10.18697/ajfand.81.15955 
Widodo, K. H., Soemardjito, J., \& Kurniawan, D. A. (2013). Supply Chain Model of Catfish Production and Trade in Yogyakarta, Indonesia. International Journal of Industrial and Manufacturing Engineering, 7(8), 16631670. https://doi.org/10.5281/zenodo. 1086638
Widyaningtyas, D., Raharto, S., \& Agustina, T. (2014). Marketing Efficiency Analysis of Arabica Coffee at Karangpring Village Sukorambi Subdistrict Jember Regency. Berkala Ilmiah Pertanian, 1 (1). Retrieved from http://repository. unej.ac.id/handle/123456789/69101, 1-10 